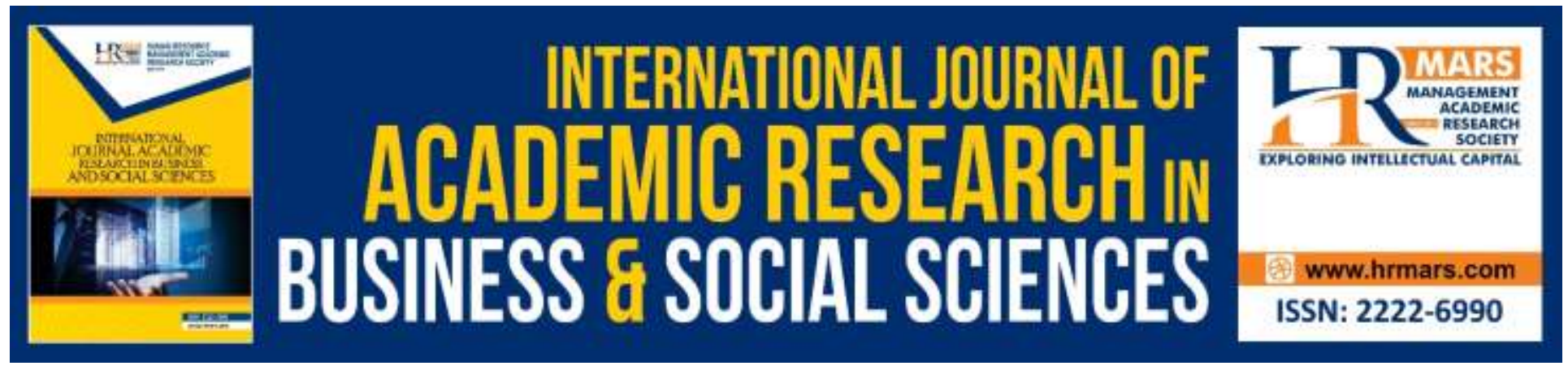

\title{
The Mediating Role of Opportunity Recognition Between Education, Experience and Venture Creation by Women Entrepreneurs in India
}

Jyoti Choudhary, Haslinda Hashim, Ho Jo Ann, Murali Sambasivan

To Link this Article: http://dx.doi.org/10.6007/IJARBSS/v10-i3/7030

DOI:10.6007/IJARBSS/v10-i3/7030

Received: 08 February 2020, Revised: 23 February 2020, Accepted: 12 March 2020

Published Online: 25 March 2020

In-Text Citation: (Choudhary et al., 2020)

To Cite this Article: Choudhary, J., Hashim, H., Ann, H. J., \& Sambasivan, M. (2020). The Mediating Role of Opportunity Recognition Between Education, Experience and Venture Creation by Women Entrepreneurs in India. International Journal of Academic Research in Business and Social Sciences, 10(3), 131-143.

Copyright: (C) 2020 The Author(s)

Published by Human Resource Management Academic Research Society (www.hrmars.com)

This article is published under the Creative Commons Attribution (CC BY 4.0) license. Anyone may reproduce, distribute, translate and create derivative works of this article (for both commercial and non-commercial purposes), subject to full attribution to the original publication and authors. The full terms of this license may be seen at: http://creativecommons.org/licences/by/4.0/legalcode

Vol. 10, No. 3, 2020, Pg. 131 - 143

http://hrmars.com/index.php/pages/detail/IJARBSS

JOURNAL HOMEPAGE

Full Terms \& Conditions of access and use can be found at http://hrmars.com/index.php/pages/detail/publication-ethics 


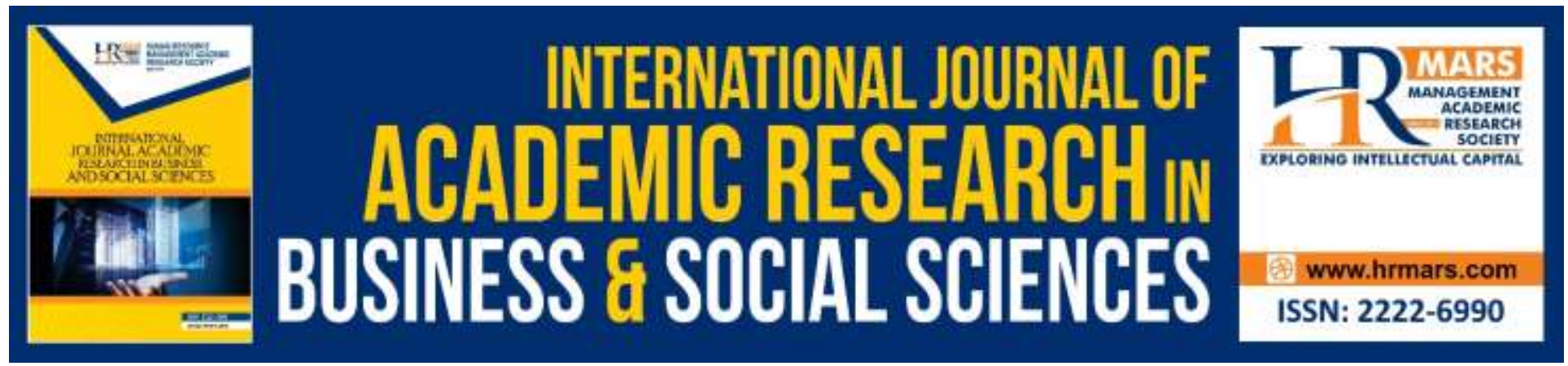

\title{
The Mediating Role of Opportunity Recognition Between Education, Experience and Venture Creation by Women Entrepreneurs in India
}

\author{
Jyoti Choudhary \\ School of Graduate Studies, Universiti Putra Malaysia, 43400 Serdang, Selangor \\ Email: jyoti_rashim@yahoo.co.in
}

Haslinda Hashim, Ho Jo Ann, Murali Sambasivan

Faculty of Economics and Management, Universiti Putra Malaysia, 43400 Serdang, Selangor

Email: haslinda@upm.edu.my, ann_hj@upm.edu.my, sambasivan@hotmail.com

\begin{abstract}
Venture creation by both, men and women are essential for economic development. However, studies suggest that gender gap in SMEs in India is highest in the world. Empirical evidence suggest that opportunity recognition is the core of venture creation. While past studies have advanced knowledge on dimensions of individual factors and identified education and experience affecting opportunity recognition, surprisingly, little knowledge have been advanced on the mediating role of opportunity recognition in education, experience and venture creation in context of women entrepreneurs in SME sector in India. The purpose of this article is therefore to propose a conceptual model integrating education, experience, opportunity recognition and venture creation. Based on the synthesis of vast amount of prior literature, a conceptual model of venture creation is developed to explain the relationships amongst the constructs under study. Consequently, testable propositions are proposed for future empirical examinations.

Keywords: Women Entrepreneurs, Individual Factors, Education, Experience, Opportunity Recognition, Venture Creation.

\section{Introduction}

Women's participation in venture creation is increasing worldwide (Agarwal \& Lenka, 2016; Corno, Lal \& Colombo, 2014; Dhekale, 2016). However, the number of women entrepreneurs is significantly lower than that of men (Othman \& Nasrudin, 2016; Tripathi, Seppänen, Boominathan, Oivo, \& Liukkunen, 2019). The gap in female entrepreneurship is especially apparent in developing economies. For example, in India only $14 \%$ of the total entrepreneurs are women [National Sample Survey Organisation (NSSO), 2013]. Not only is the gender gap high,
\end{abstract}


women entrepreneurs are predominantly operating in the micro sector in India, suggesting even higher gender gap in SME sector (Adomako, Danso, \& Ampadu, 2015; Holienka, Jančovičová, \& Kovačičová, 2016; Jennings \& Brush, 2013a). When women do not participate equally in entrepreneurship, and their scale of operation is micro, economies loose the benefits that would otherwise be provided by new products and services, additional revenues, and new jobs (Mutalib \& Ahmad, 2015; Pettersson, Ahl, Berglund, \& Tillmar, 2017). Without boosting women's economic participation in SMEs, it will be very challenging for economies to achieve the 2030 agenda for Sustainable Development Goals (SDGs) and to reach their full economic and social potential (IfC, World Bank Group, 2016).

Recent researches suggest that the gender gap is high in India due not only to low success rate of women owning businesses but also because very few women are starting businesses (Arruda, Nogueira \& Cozzi, 2015; Junquera, 2015). The process of venture creation begins with the recognition of opportunities (Ozgen \& Baron, 2007; Shane \& Nicolaou, 2015; Wharton, Brunetto, \& Farr-wharton, 2013). Then entrepreneur evaluates these opportunities and decides if they want to exploit them through venture creation (Correia, António, Robert, \& Luís, 2016; Shane \& Nicolaou, 2015). Researchers have noted that both men and women use different sources for opportunity recognition and women find it more challenging than men (Ahunov \& Yusupov, 2017; Husna, Rahim, Fabeil, \& Sung, 2017). This issue becomes even more imminent after acknowledging that challenges women faces operating at the micro-level are different from women operating at small and medium levels (Durkin, McGowan, \& McKeown, 2013; Mpeera Ntayi, Mutebi, Byangwa, \& Georgina Kamanyi, 2014). Consequently, it becomes imperative to revisit various factors influencing opportunity recognition and consequently venture creation.

Human capital, which comprise of education and experience have been recognized as antecedents for awareness of business opportunities (Ardichvili \& Cardozo, 2000; Brockman, 2014; Gaglio \& Katz, 2001). Education received in a systematic way within a school or university (Teixeira \& Davey, 2010) and experience acquired because of doing an activity for a long time (Canedo et al., 2014) will influence awareness of an individual. The increased awareness can help entrepreneurs to identify possible opportunities better than those without education and experience. Thus, it follows that level of education and experience can be a distinguishing factor in the choice of entrepreneurial activity. However, the inconclusiveness of results about relationship between education, experience, opportunity recognition and venture creation and ignoring the influence of gender, context, scale and type of ventures created by individuals, in establishing this relationship, have still left the scholars baffled (Seet \& Ahmad, 2015; Tripathi et al., 2019). Women have less access to education and previous job experience, in comparison to men. Also, it is established that women have degrees in liberal arts, unlike men who hold degree in STEM field. Further, venture owned by women are mainly in retail and service sector, unlike men who are mainly found owning ventures in manufacturing sector. In addition, women previous job experience is disrupted due to marriage and child rearing. Thus, it becomes imperative to understand the influence of education and experience on the opportunity recognition ability of women, considering the choice of sector and size of ventures created by them. 
Furthermore, studies have mainly identified opportunity recognition as mediating variable in individual factors and venture performance of established businesses (Patanakul \& Pinto, 2014; Sambasivan, Abdul, \& Yusop, 2009a; Zhu, Burmeister-Lamp, \& Hsu, 2017). Very little efforts have been made to examine the relationships between education and experience on new venture creationthrough the mediating role of opportunity recognition (Naser, Rashid Mohammed, \& Nuseibeh, 2009). To the researchers' best knowledge, no study has investigated the relationships amongst education, experience, opportunity recognition and venture creation in context of women entrepreneurs owning SMEs in a single integrated framework. This study therefore intends to address this gap by proposing mediating role of opportunity recognition between education, experience and venture creation by women entrepreneurs.

\section{Women Entrepreneurship in India}

A woman entrepreneur is defined as women, who initiate, organize and operate a business enterprise (Sharma, 2013a). Earlier, women in India were associated with three K's - Kitchen, Kids and Knitting. Then came three P's - Powder, Papad (Indian snack) and Pickles. In urban India, women, entrepreneurs are found in four E's- Electricity, Electronics, Energy and Engineering. Today, women are found in various sectors in India including manufacturing, trading services and IT enabled services (Kungwansupaphan \& Leihaothabam, 2016; Sharma, 2013b). However, majority of women entrepreneurs operate in micro sector and there is a persistent gender gap. India presents a setting in which women entrepreneurs face challenges to venture creation stemming from a myriad of sources (Pareek \& Bagrecha, 2017). This is particularly true with respect to the patriarchal nature of Indian society and women's family responsibilities (Dhekale, 2016). Indian women have also been at disadvantage in having access to key entrepreneurial resources, for example, education, experience, funds and technological knowhow (Jha, 2018; Kungwansupaphan \& Leihaothabam, 2016).

\section{Venture Creation}

According to Gartner (1985), venture creation is a process of planning, organizing, and establishing new organizations. The process of venture creation starts with motivation and then moves on to opportunity identification, resource acquisition, performance and ultimately success (Baron, 2011). In other words, venture creation process encompasses a) entrepreneurial intent, b) opportunity search and finally c) the decision to exploit it by new venture creation. Based on these reflections, entrepreneurial process is viewed as the succession of the opportunity-related process (recognition - evaluation - exploitation). Thus, opportunity recognition forms the basis of venture creation.

\section{Opportunity Recognition}

Opportunity recognition is defined as a process whereby individuals identify and recognize, potential opportunities to create and develop new ventures (Andrea, Jim, \& Wang, 2013). Opportunity recognition is characterized as being alert to potential business opportunities, actively searching for these opportunities, gathering information and evaluating the viability of such potential entrepreneurial activities. Since people need to identify opportunities to be 
entrepreneurs, skill at opportunity identification increases the probability that a person will become an entrepreneur.

Women entrepreneurs face numerous challenges in recognising opportunities and creating business due to lack of education, skills, experience and self-confidence. Also the fear of failure to start a new venture is high in comparison to men (Jennings \& Brush, 2013b). Hence, numerous individual factors have been researched by scholars like education, experience, motivation, entrepreneurial orientation, age, marital status (Hani, Rachmania, Setyaningsih, \& Putri, 2012; Sriram, Mersha, \& Herron, 2007). Amongst many individual factors, education and experience has been established by scholars to play an influential role in identifying opportunities (Hajizadeh \& Zali, 2016; Sharif, 2015; Venesaar, Kallaste, \& Küttim, 2014).

Considering, women have less access to education and less number of years of job experience in comparison to men and that it becomes discontinuous due to marriage and child bearing, the literature suggests to investigate the relationship between education and experience with opportunity recognition and venture creation in context of women entrepreneurs (Hassan, Osman, \& Rashid, 2011; Jennings \& Brush, 2013b).

\section{Relationship between education and opportunity recognition among women entrepreneurs}

Education of a person may be helpful in two ways. First, it is helpful in generating necessary cognitive skills in an individual so that he/she can effectively evaluate the opportunities as they arise (Giacomin, 2011; Pérez-pérez \& Avilés-hernández, 2016). Second, education also increases person's self-confidence which facilitate the person to explore more entrepreneurial activities (Hannah, Thomas, Noke, \& Chesney, 2014). However, the findings on the potential effect of education on the opportunity recognition and venture creation are inconsistent in the literature (Jiménez, Palmero-cámara, González-santos, González-bernal, \& Jiménez-eguizábal, 2015; Rauth Bhardwaj, 2014a). Some studies report that education is positively associated with the likelihood to recognize opportunities (Brush, Ali, Kelley, \& Greene, 2017; McCracken, Mclvor, Treacy, \& Wall, 2017). Other studies find no relationship (Ploum, Blok, Lans, \& Omta, 2018; Sluis, Praag, \& Vijverberg, 2008). Finally, some research suggests that it is important to consider the type of education. Higher education may not have an additional positive effect on entry into entrepreneurship (Africa, Peters, \& Brijlal, 2014). Some researchers suggest that it is important to consider the type of business and scale of operations (Simmons \& Hornsby, 2014; Welsh, Memili, Kaciak, \& Catharines, 2016), while understanding the influence of education on venture creation It has been established that education has a significant impact on business of technical , engineering and innovative nature (Jha, 2018)

In addition to inconclusiveness of the findings about relationship between education and opportunity recognition, there is dearth of studies examining this relationship in context of women entrepreneur creating SMEs. Despite inconclusive findings most researches across nations have agreed to a positive relationship between education and opportunity recognition 
INTERNATIONAL JOURNAL OF ACADEMIC RESEARCH IN BUSINESS AND SOCIAL SCIENCES

Vol. 10, No. 3, March, 2020, E-ISSN: 2222-6990 @ 2020 HRMARS

(Heuër, 2017; Prasad, Naidu, Murthy, \& Doan, 2013 Estrin et al., 2016; Rauth Bhardwaj, 2014b). Hence, we propose the following:

Proposition 1 - There is a positive relationship between education and opportunity recognition among women entrepreneurs.

\section{Relationship between experience and opportunity recognition among women entrepreneurs}

The capability of an individual to discover, develop and utilize an opportunity is dependent on his/her prior knowledge and experience (Carr \& Sequeira, 2007a; Hannah, Thomas, Noke, \& Chesney, 2014). The expertise gathered from experience may surge an entrepreneur's ability to recognize and exploit market opportunities, as well as better understand the desires of customers in that industry (Arentz, Sautet, \& Storr, 2013; Heuër, 2017). As a result, this expertise may provide experienced entrepreneurs an important source of competitive advantage over others (Jacobs \& Bu-Rahmah, 2012; Naser, Mohammed, \& Nuseibeh, 2009).

However, it is also been noted that women tend to have less experience in comparison to men because of the factors like gender bias, which does not give them enough opportunities to work and learn, early marriage and child bearing. Further, this experience become discontinuous due to primary responsibility of rearing a child on women in patriarchal societies like India. Thus, the influence of experience on opportunity recognition in context of women entrepreneurs needs to be investigated. Hence, based on human capital theory and the findings of previous studies authors propose the following:

Proposition 2: There is a positive relationship between experience and opportunity recognition among women entrepreneurs.

\section{Relationship between education and venture creation among women entrepreneurs}

Several studies find that education is positively related to the likelihood of being a business founder (Brush et al., 2017; Estrin et al., 2016; McCracken et al., 2017). As creating a new business is a process fraught with difficulty the more knowledge acquired through education, nascent entrepreneur has higher chances of success in venture creation (Hannah et al., 2014). Studies exploring education as a predictor of venture creation, however, have not proven as conclusive. In some developed economies like Singapore and Belgium, negative relationship between education and venture creation has been established (Prasad et al., 2013).

Not only are the findings on the relationship between education and venture creation inconclusive, there is dearth of studies exploring this relation in context of women entrepreneurs. Women, particularly, in developing countries have less access to education in comparison to men due to various socio-cultural factors (Hani et al., 2012; Kanojia Palak \& Verma Kirti, 2016). In addition women creating technical businesses are less in comparison to men where education plays a considerable role (Jha, 2018). Thus, it is suggested to explore further the complexity of 
INTERNATIONAL JOURNAL OF ACADEMIC RESEARCH IN BUSINESS AND SOCIAL SCIENCES

Vol. 10, No. 3, March, 2020, E-ISSN: 2222-6990 @ 2020 HRMARS

this relation in the context of women entrepreneurship. Based on the findings from the previous studies and human capital theory authors propose:

Proposition 3- There is a positive relationship between education and venture creation among women entrepreneurs.

\section{Relationship between Experience and Venture Creation among Women Entrepreneurs}

Human capital is not only the result of education, but also includes experience and practical learning that takes place on the job (Staniewski, 2016). Studies show that greater extent of job experience is positively related to new venture creation (Brush et al., 2017; McCracken et al., 2017). However, women in India have less job experience in comparison to men. Their participation in labour force is quite low. Less than a third of adult women in India are working or actively looking for a job (World Bank, 2018). In addition, researchers have observed that in comparison to men, women give more importance to attain work life balance and fulfilment over experience, while making entrepreneurial choices. Due to inconclusiveness on the relation between experience and venture creation in context of women, it becomes imperative to explore this relationship. Based on the evidences from literature that entrepreneurs use existing stock of knowledge to be entrepreneurial (Corno et al., 2014; Naser, Mohammed, et al., 2009; Shastri \& Rao, 2014) we propose that:

Proposition 4- There is a positive relationship between experience and venture creation among women entrepreneurs.

\section{Mediating Role of Opportunity Recognition}

Existing literatures have established that venture creation is a consequence of an entrepreneur's opportunity recognition ability. Since individual factors such as education and experience can enhance opportunity recognition skills, which can further increase the possibility of venture creation (Terjesen, Hessels, \& Li, 2013; Verheul, van Stel, \& Thurik, 2006; Bruton et al., 2010; Nyström, 2008), we argue that opportunity recognition mediates the relationship of individual and institutional factors with venture creation. To the best of the researcher's knowledge, no prior studies have investigated the mediation effect of opportunity recognition on the relationship of individual and institutional factors with venture creation, particularly in the context of women-owned SMEs in India. Previous researchers have examined this relationship on the performance of established ventures (Sambasivan, Abdul, \& Yusop, 2009b; Wharton et al., 2013). Thus, we propose that:

Proposition 5- Opportunity recognition is a mediator between education and venture creation Proposition 6- Opportunity recognition is a mediator between experience and venture creation

\section{Research Framework}

Based on the review of literature and objectives of the study as explained in earlier sections, a conceptual framework (see figure 1) has been developed to show the relationships amongst individual factors (considering the dimensions of education and experience), opportunity 
recognition and venture creation. The current study, drawing from the Resource Based View and Human capital theory argue that the education and job experience will enhance the opportunity recognition of women entrepreneurs and will thereby increase venture creation by women entrepreneurs in India. In this regard, opportunity recognition will mediate the relationship between education, experience and venture creation by women entrepreneur in India. The framework has two exogenous variables, one mediating variable and one endogenous variable.

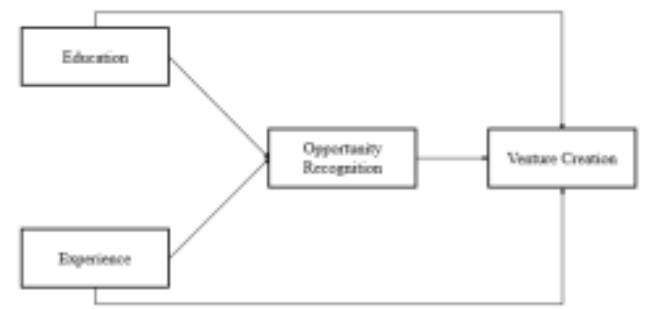

Figure: 1 Proposed Conceptual framework linking education and experience with opportunity recognition and venture creation

\section{Conclusion/Implications}

There is a crucial need for understanding the factors that can enhance opportunity recognition among women entrepreneurs. Interest on increasing venture creation by women entrepreneurs is on the rise. However, this untapped potential of Indian economy can be encouraged to commence entrepreneurial journey by enhancing opportunity recognition ability of women, which is the core of venture creation. In previous studies, education and experience have been accepted to influence opportunity recognition by an individual. However, researchers have ignored the influence of context, gender, scale and type of businesses owned by entrepreneurs while establishing this relationship. Also, the antecedents and outcome of opportunity recognition have not been established in the same framework. To recognise opportunities, it is important to understand the influence of education and experience in context of women, considering women have less access to both of them these. The study proposes to examine the possible direct effects of education and experience on opportunity recognition and venture creation in context of women entrepreneur in India creating SMEs. Additionally this study proposes to investigate the possible mediating role of opportunity recognition between education experience and venture creation by women entrepreneurs in India.

Present study contributes to the understanding if education and experience influence opportunity recognition and venture creation by women entrepreneurs in a similar way as it affects men. Another contribution that this study hopes to make is to establish that opportunity recognition mediates the relationship between individual factors and new venture creation by women entrepreneurs in SMEs. Practically, the study hopes to draw the attention of policy makers if there is a need to increase education and employment avenues for women to increase their participation in entrepreneurship. In addition, the empirical testing of this proposed model could provide empirical evidence on the role of education and experience for women entrepreneurs, and which of these factors are valued more by women entrepreneurs. 
INTERNATIONAL JOURNAL OF ACADEMIC RESEARCH IN BUSINESS AND SOCIAL SCIENCES

Vol. 10, No. 3, March, 2020, E-ISSN: 2222-6990 @ 2020 HRMARS

\section{References}

Adomako, S., Danso, A., \& Ampadu, E. (2015). Institutional outlook of the entrepreneurial climate in Ghana. International Journal of Social Economics, 42(6), 566-582. http://doi.org/10.1108/IJSE-09-2013-0206

Agarwal, S., \& Lenka, U. (2016). An exploratory study on the development of women entrepreneurs: Indian cases. Journal of Research in Marketing and Entrepreneurship, 18(2). http://doi.org/10.1108/JRME-04-2015-0024

Ahunov, M., \& Yusupov, N. (2017). Risk attitudes and entrepreneurial motivations: Evidence from transition economies. Economics Letters, 160, 7-11. http://doi.org/10.1016/j.econlet.2017.08.016

Ardichvili, A., \& Cardozo, R. N. (2000). A Model of the Entrepreneurial Opportunity Recognition Process. Journal of Enterprising Culture, 8, 103-119 http://doi.org/10.1142/S0218495800000073

Arentz, J., Sautet, F., \& Storr, V. (2013). Prior-knowledge and opportunity identification. Small Business Economics, 41, 461-478. http://doi.org/10.1007/s11187-012-9437-9

Arruda, C., Nogueira, V. S., \& Cozzi, A. (2015). Entrepreneurship in BRICS. http://doi.org/10.1007/978-3-319-11412-5

Brockman, B. K. (2014). Entrepreneurial alertness in opportunity identification and opportunity development. Journal of Business and Entrepreneurship, 26, 27-44.

Brush, C., Ali, A., Kelley, D., \& Greene, P. (2017). The influence of human capital factors and context on women's entrepreneurship: Which matters more? Journal of Business Venturing Insights, 8(August), 105-113. http://doi.org/10.1016/j.jbvi.2017.08.001

Canedo, J. C., Stone, D. L., Black, S. L., \& Lukaszewski, K. M. (2014). Individual factors affecting entrepreneurship in Hispanics. Journal of Managerial Psychology, 29(6), 755-772. http://doi.org/10.1108/JMP-11-2012-0333

Carr, J. C., \& Sequeira, J. M. (2013). Prior family business exposure as intergenerational influence and entrepreneurial intent: A Theory of Planned Behavior approach. Journal of Business Research, 60(10), 1090-1098. http://doi.org/10.1016/j.jbusres.2006.12.016

Corno, F., Lal, R., \& Colombo, S. (2014). Entrepreneurship and new venture creation-Key elements of the entrepreneurial ecosystem facilitating the growth of ICT Entrepreneurs in Italy. European Scientific Journal, 2(September), 1857-7881.

Dhekale, V. S. (2016). Performance of Women Entrepreneurship in India. International Journal of Management, 7(1), 123-131. http://www.iaeme.com/IJM/issues

Durkin, M., McGowan, P., \& McKeown, N. (2013). Exploring social media adoption in small to medium-sized enterprises in Ireland. Journal of Small Business and Enterprise Development, 20(4), 716-734. http://doi.org/10.1108/JSBED-08-2012-0094

Estrin, S., Mickiewicz, T., \& Stephan, U. (2016). Human capital in social and commercial entrepreneurship. Journal of Business Venturing, 31(4), 449-467. http://doi.org/10.1016/j.jbusvent.2016.05.003

Fabeil, N. F., Toh, S., \& Sung, P. (2017). Motivator and Challenges of Women. 1(February), 111121.

Farr-Wharton, R., \& Brunetto, Y. (2007). Women entrepreneurs, opportunity recognition and government-sponsored business networks: A social capital perspective. Women in 
INTERNATIONAL JOURNAL OF ACADEMIC RESEARCH IN BUSINESS AND SOCIAL SCIENCES

Vol. 10, No. 3, March, 2020, E-ISSN: 2222-6990 @ 2020 HRMARS

Management Review, 22(3), 187-207. http://doi.org/10.1108/09649420710743653

Gaglio, C. M., \& Katz, J. A. (2001). The psychological basis of opportunity identification: entrepreneurial alertness. Small Business Economics, 16, 95-111. http://doi.org/10.1023/A:1011132102464

Gartner, W. B., \& Shane, S. A. (1995). Measuring entrepreneurship over time. Journal of Business Venturing, 10(4), 283-301. http://doi.org/10.1016/0883-9026(94)00037

Ghani, E., Kerr, W., \& Connell, S. D. O. (2013). Promoting Women's Economic Participation in India. Journal of Development Economics, (107), 1-6

Hajizadeh, A., \& Zali, M. (2016). Prior knowledge, cognitive characteristics and opportunity recognition. International Journal of Entrepreneurial Behaviour and Research, 22(1), 6383. http://doi.org/10.1108/IJEBR-05-2015-0110

Hani, U., Rachmania, I. N., Setyaningsih, S., \& Putri, R. C. (2012). Patterns of Indonesian Women Entrepreneurship. Procedia Economics and Finance, 4(Icsmed), 274-285. http://doi.org/10.1016/S2212-5671(12)00342-5

Hassan, M., Osman, M., \& Rashid, M. A. (2011). Market orientation - a missing link to successful women entrepreneurship in developing countries : a conspectus of literature. 3(4), 232237.

Heuër, A. (2017). Women-to-women entrepreneurial energy networks: A pathway to green energy uptake at the base of pyramid. Sustainable Energy Technologies and Assessments, 22, 116-123. http://doi.org/10.1016/j.seta.2017.02.020

Holienka, M., Jančovičová, Z., \& Kovačičová, Z. (2016). Drivers of Women Entrepreneurship in Visegrad Countries: GEM Evidence. Procedia - Social and Behavioral Sciences, 220(March), 124-133. http://doi.org/10.1016/j.sbspro.2016.05.476

IFC, World Bank Group, \& Govt of Japan. (2016). Improving Access to Finance for Women owned businesses in India. International Business Review, 48.

Jacobs, R. L., \& Bu-Rahmah, M. J. (2012). Developing employee expertise through structured onthe-job training (S-OJT): an introduction to this training approach and the KNPC experience. Industrial and Commercial Training, 44(2), 75-84.

http://doi.org/10.1108/00197851211202902

Jennings, J. E., \& Brush, C. G. (2013a). Research on Women Entrepreneurs : Challenges to (and from) the Broader Entrepreneurship Literature? Academy of Management Annals, $7(1)$, $663-715$.

Jennings, J. E., \& Brush, C. G. (2013b). Research on Women Entrepreneurs : Challenges to (and from) the Broader Entrepreneurship Literature? Academy of Management Annals, 7(1), $663-715$.

Jha, S. K. (2018). Entrepreneurial ecosystem in India: Taking stock and looking ahead. IIMB Management Review, 30(2), 179-188. http://doi.org/10.1016/j.iimb.2018.04.002

Jiménez, A., Palmero-cámara, C., González-santos, M. J., González-bernal, J., \& Jiménezeguizábal, J. A. (2015). informal entrepreneurship. Cuadernos de Economía y Dirección de La Empresa. http://doi.org/10.1016/j.brq.2015.02.002

Junquera, B. (2015). Where does female entrepreneurial human capital come from? A review of the literature. Innovation Management, Policy \& Practice ISSN:, 9338(September). http://doi.org/10.5172/impp.2011.13.3.391 
INTERNATIONAL JOURNAL OF ACADEMIC RESEARCH IN BUSINESS AND SOCIAL SCIENCES

Vol. 10, No. 3, March, 2020, E-ISSN: 2222-6990 @ 2020 HRMARS

Kar, B., Subudhi, R. N., \& Kar, N. (2016). Gender-Gap in Entrepreneurship: A Study on Ideation, Efficacy, Planning Differentiation Measures. In AJE ADMAA Amity Journal of Entrepreneurship (Vol. 1).

Kungwansupaphan, C., \& Leihaothabam, J. K. S. (2016). Capital factors and rural women entrepreneurship development. Gender in Management: An International Journal, 31(3), 207-221. http://doi.org/10.1108/GM-04-2015-0031

McCracken, M., Mclvor, R., Treacy, R., \& Wall, T. (2017). A study of human capital reporting in the United Kingdom. Accounting Forum, (November), 0-1. http://doi.org/10.1016/j.accfor.2017.11.001

Ntayi, M. J., Mutebi, H., Byangwa, K., \& Georgina Kamanyi, S. (2014). Institutional framing and entrepreneurship capital in Uganda. World Journal of Entrepreneurship, Management and Sustainable Development, 10(3), 177-197. http://doi.org/10.1108/WJEMSD-072013-0037

Mutalib, R. A., \& Ahmad, Z. (2015). Women and Entrepreneurship : An Overview of Women Entrepreneurship Programs in Malaysia. JGD Vol. 11, Special Issue on Social Entrepreneurship, January 2015, 15-28 Malaysia, 11(January), 15-28.

Naser, K., Mohammed, W. R., \& Nuseibeh, R. (2009). Factors that affect women entrepreneurs: evidence from an emerging economy. International Journal of Organizational Analysis, 17, 225-247. http://doi.org/10.1108/19348830910974932

NSSO Annual Report. (2013). Women entrepreneur statistics, 81. http://data.gov.in

Noke, H., \& Chesney, T. (2014). Prior knowledge: the role of virtual worlds in venture creation. Journal of Small Business and Enterprise Development, 21(3), 403-413. http://doi.org/10.1108/JSBED-04-2014-0057

Othman, N., \& Nasrudin, N. (2016). Entrepreneurship education programs in Malaysian polytechnics. Education + Training, 58(7/8), 882-898. http://doi.org/10.1108/ET-112014-0136

Ozgen, E., \& Baron, R. A. (2011). Social sources of information in opportunity recognition: Effects of mentors, industry networks, and professional forums. Journal of Business Venturing, 22, 174-192. http://doi.org/10.1016/j.jbusvent.2005.12.001

Pareek, P., \& Bagrecha, C. (2017). A Thematic Analysis of the Challenges and Work-Life Balance of Women Entrepreneurs Working in Small-Scale Industries. Vision, 21(4), 461-472. http://doi.org/10.1177/0972262917739181

Patanakul, P., \& Pinto, J. K. (2014). Examining the roles of government policy on innovation. Journal of High Technology Management Research, 25(2), 97-107. http://doi.org/10.1016/j.hitech.2014.07.003

Pérez-pérez, C., \& Avilés-hernández, M. (2016). Explanatory factors of female entrepreneurship and limiting elements. Suma de Negocios, 7(15), 4-10. http://doi.org/10.1016/j.sumneg.2015.12.004

Peters, R. M., \& Brijlal, P. (2011). The Relationship between Levels of Education of Entrepreneurs and Their Business Success: A Study of the Province of Kwazulu-Natal, South Africa. Industry and Higher Education, 25(4), 265-275. http://doi.org/10.5367/ihe.2011.0048

Pettersson, K., Ahl, H., Berglund, K., \& Tillmar, M. (2017). In the name of women? Feminist readings of policies for women's entrepreneurship in Scandinavia. Scandinavian Journal 
INTERNATIONAL JOURNAL OF ACADEMIC RESEARCH IN BUSINESS AND SOCIAL SCIENCES

Vol. 10, No. 3, March, 2020, E-ISSN: 2222-6990 @ 2020 HRMARS

of Management, 33(1), 50-63. http://doi.org/10.1016/j.scaman.2017.01.002

Pi-Shen, S., Hazlina, N., \& Lip-Chai, S. (2008). Singapore's female entrepreneurs are they different? International Journal of Entrepreneurship and Small Business, 5(3-4), 257-271. http://doi.org/10.1504/IJESB.2008.017303

Ploum, L., Blok, V., Lans, T., \& Omta, O. (2018). Exploring the relation between individual moral antecedents and entrepreneurial opportunity recognition for sustainable development. Journal of Cleaner Production, 172, 1582-1591. http://doi.org/10.1016/j.jclepro.2017.10.296

Prasad, V. K., Naidu, G. M., Kinnera Murthy, B., Winkel, D. E., \& Ehrhardt, K. (2013). Women entrepreneurs and business venture growth: an examination of the influence of human and social capital resources in an Indian context. Journal of Small Business and Entrepreneurship, 26(4), 341-364. http://doi.org/10.1080/08276331.2013.821758

Rauth Bhardwaj, B. (2014a). Impact of education and training on performance of women entrepreneurs. Journal of Entrepreneurship in Emerging Economies, 6(1), 38-52. http://doi.org/10.1108/JEEE-05-2013-0014

Rauth Bhardwaj, B. (2014b). Impact of education and training on performance of women entrepreneurs. Journal of Entrepreneurship in Emerging Economies, 6(1), 38-52. http://doi.org/10.1108/JEEE-05-2013-0014

Sambasivan, M., Abdul, M., \& Yusop, Y. (2009a). Impact of personal qualities and management skills of entrepreneurs on venture performance in Malaysia: Opportunity recognition skills as a mediating factor. Technovation, 29(11), 798-805.

http://doi.org/10.1016/j.technovation.2009.04.002

Sambasivan, M., Abdul, M., \& Yusop, Y. (2009b). Impact of personal qualities and management skills of entrepreneurs on venture performance in Malaysia: Opportunity recognition skills as a mediating factor. Technovation, 29(11), 798-805. http://doi.org/10.1016/j.technovation.2009.04.002

Santos, S. C., Caetano, A., Baron, R., \& Curral, L. (2015). Prototype models of opportunity recognition and the decision to launch a new venture: Identifying the basic dimensions. International Journal of Entrepreneurial Behaviour and Research, 21(4), 510-538. http://doi.org/10.1108/IJEBR-04-2014-0058

Shane, S., \& Nicolaou, N. (2015). Creative personality, opportunity recognition and the tendency to start businesses: A study of their genetic predispositions. Journal of Business Venturing, 30, 407-419. http://doi.org/10.1016/j.jbusvent.2014.04.001

Sharif, M. Y. (2015). Glass ceiling, the prime driver of women entrepreneurship in Malaysia: A phenomenological study of women lawyers. Procedia - Social and Behavioral Sciences, 169(August 2014), 329-336. http://doi.org/10.1016/j.sbspro.2015.01.317

Sharma, Y. (2013a). Women Entrepreneur In India. IOSR Journal of Business and Management, 15(3), 9-14. http://doi.org/10.9790/487X-1530914

Sharma, Y. (2013b). Women Entrepreneur In India. IOSR Journal of Business and Management, 15(3), 09-14. http://doi.org/10.9790/487X-1530914

Shastri, D., \& Rao, U. T. (2014). Women Entrepreneurs of Gujarat. Procedia Economics and Finance, 11(14), 745-752. http://doi.org/10.1016/S2212-5671(14)00238-X

Simmons, S. a., \& Hornsby, J. S. (2014). Academic Entrepreneurship: Creating An Entrepreneurial 
INTERNATIONAL JOURNAL OF ACADEMIC RESEARCH IN BUSINESS AND SOCIAL SCIENCES

Vol. 10, No. 3, March, 2020, E-ISSN: 2222-6990 ¿ 2020 HRMARS

Ecosystem. Advances in Entrepreneurship, Firm Emergence and Growth, 16, 37-66. http://doi.org/10.1108/S1074-754020140000016000

Sivanesan, R. (2014). A comparative study on rural and urban women entrepreneurs - Prospects and challenges. International Journal of Research in Management and Business Studies, 1(3), 28-34.

Sriram, V., Mersha, T., \& Herron, L. (2007). Drivers of urban entrepreneurship: an integrative model. International Journal of Entrepreneurial Behaviour \& Research, 13(4), 235-251. http://doi.org/10.1108/13552550710760012

Staniewski, M. W. (2016). The contribution of business experience and knowledge to successful entrepreneurship. Journal of Business Research, 69(11), 5147-5152. http://doi.org/10.1016/j.jbusres.2016.04.095

Teixeira, A. A. C., \& Davey, T. (2010). Attitudes of higher education students to new venture creation The relevance of competencies and contextual factors. Industry and Higher Education, 24(5), 323-341. http://doi.org/10.5367/ihe.2010.0005

Tripathi, N., Seppänen, P., Boominathan, G., Oivo, M., \& Liukkunen, K. (2019). Insights into startup ecosystems through exploration of multi-vocal literature. Information and Software Technology, 105(August 2018), 56-77. http://doi.org/10.1016/j.infsof.2018.08.005

Van Der Sluis, J., Van Praag, M., \& Vijverberg, W. (2008). Education and entrepreneurship selection and performance: A review of the empirical literature. Journal of Economic Surveys, Vol. 22, pp. 795-841. http://doi.org/10.1111/j.1467-6419.2008.00550.x

Venesaar, U., Kallaste, M., \& Küttim, M. (2014). Factors influencing students ' venture creation process. Procedia - Social and Behavioral Sciences, 110, 678-688. http://doi.org/10.1016/j.sbspro.2013.12.912

Wang, Y. L., Ellinger, A. D., \& Wu, Y. C. J. (2013). Entrepreneurial opportunity recognition: An empirical study of R\&D personnel. Management Decision, 51(2), 248-266. http://doi.org/10.1108/00251741311301803

Welsh, D. H. B., Memili, E., Kaciak, E., \& Catharines, S. (2016). Journal of Innovation Empirical paper support on Turkish women entrepreneurs \&. Suma de Negocios, 1(1), 3-12. http://doi.org/10.1016/j.jik.2016.01.012

World bank report on entrepreneurship in India. (2018). India soars higher.

Zhu, F., Burmeister-Lamp, K., \& Hsu, D. K. (2017). To leave or not? The impact of family support and cognitive appraisals on venture exit intention. International Journal of Entrepreneurial Behavior \& Research, 23(3), 566-590. http://doi.org/10.110 